\title{
АСПЕКТИ СТАНОВЛЕННЯ МІЖНАРОДНОГО ПРАВА У СФЕРІ ОХОРОНИ ПРАВ ДІТЕЙ
}

\author{
СТАРИЧЕНКО Алевтина Олександрівна - ад'юнкт Одеського державного \\ університету внутрішніх справ
}

DOI:10.32782/NP.2020.1.8

УДК 342.722.1-053.2

В статье осуществлен анализ развития и становления международного права в сбере охранъ и защиты прав детей. Исследовались источники ювенального права от первичного представления о правах ребенка в Античнъе времена, до бормирования на современном этапе устойчивой системъ международнъих нормативно-правовых актов. Приведенъ примерв понимания прав детей в доиндустриальной период. Обгясняются причинъ активизачии развития идей охранъ и защить прав ребенка и растуший интерес к этой проблеме в начале $X X$ в. влияниемм на гражданское население последствий Первой мировой войнъ. Приведена хронология принятия международныхх нормативно-правовых актов в сбере охранъг и защить прав детей.

Сделан въвод, что развитие международного права относительно охранъг и защить прав детей указывает на то, ито нъинешнее его состояние это результат длительного и довольно противеречивого становления. Повъишенный интерес общества к решению проблемь охранв и защитьл прав детей свидетельствует о развитии ценностей детства, забота о подрастающем поколение на международном уровне.

Ключевъе слова: ребенок, права, свободъ, интересъ ребенка, ювенальная политика, обеспечение прав и свобод ребенка, охрана прав ребенка, Конвениия о правах ребенка.

\section{Постановка проблеми}

Розвиток у сучасному суспільстві гуманістичних та дитиноцентричних цінностей призводить до розуміння проблеми охорони та захисту прав дітей, а також до розробки механізмів їхнього забезпечення. Виключення із суспільних відносин практики насильства над дитиною є запорукою гармонійного розвитку особистості, а головне те, що в майбутньому молоде покоління само уникатиме жорстокості до своїх дітей.

Багатьом видається, що порушення прав дітей - це поодинокі, кричущі випадки, пов'язані з насильством та які властиві лише певним соціальним категорія (з важким економічним становищем, розладами психіки або низьким рівнем освіти батьків). Однак реальна картина, на превеликий жаль, виглядає по-іншому. Порушення прав дітей, і це стверджують більшість дослідників у галузі ювенального права, - це складне системне соціокультурне явище, яке відображає ступінь зрілості суспільства, соціального, економічного та психічного благополуччя кожного його члена.

Рівень наукової розробки проблеми

Питання правового забезпечення, охорони та захисту прав дітей грунтовно розробляли як зарубіжні, так і вітчизняні дослідникии B.I. Абрамов, А.С. Автономов, Н.О. Архіпова, Т.В. Бачинський, І.В. Волошина, О.I. Волокітенко, I.В. Волощук, А.М. Грищук, О.М. Дручек, О.Е. Журавель, 
В.О. Закриницька, В.С. Зеленецький, Т.А. Кальченко, Т.Г. Корж-Ікаєва, С.П. Коталейчук, Н.М. Крестовська, О.М. Кудрявцева, О.О. Лазоренко, Н.В. Аесько, О.В. Максименко, I.ภ. Михайлова, В.Ю. Москалюк, О.В. Нікітенко, Н.М. Онищенко, Р.М. Опацький, Н.М. Опольська, С.Г. Поволоцька, Ж.М. Пустовіт, С.А. Саблук, Е.П. Филипенко, О.В. Черевач, I.В. Швець, О.А. Шульц та інші.

\section{Виклад основного матеріалу}

Захист прав людини є однією з найважливіших галузей сучасного міжнародного права, його історія сягає у далеке в минуле, а процес становлення складався не просто. Перші правові норми, направлені на регулювання прав дитини, були присутні в національному праві античної Греції та Римської держави, однак з позиції сучасності можуть нас шокувати своїм варварством.

Наприклад, давньогрецька правова традиція щодо поводження 3 дітьми не передбачала не лише покарання, а навіть суспільного осуду за залишення напризволяще новонародженої дівчинки від якої позбувались родини, у яких народилося кілька дівчаток [1, с.39].

Давньоримська рання суспільно-правова традиція, що мало чим відрізнялась від традиції еллінської, відзначалося більш жорстким порядком поводження 3 дітьми у родині. Тут влада батька над дітьми була абсолютною, він міг позбутись дитини викинувши їі або вбити шляхом удушення. У той же час дитина народжена від римських громадян не могла бути предметом купівлі-продажу [2, с.148].

У Китаї необмежена влада на дітьми, як сімейно-правова традиція, панувала 3 давніх часів майже до середини XIX століття. Батько мав право продавати дітей, окрім старшого сина, що користувався низкою переваг перед іншими дітьми [3].

У доісламській Аравії позбутись небажаних дівчаток шляхом залишення в пустелі, чи закопуванням у землю, також вважалось суспільно прийнятним вчинком. ᄉише з приходом ісламу такі вчинки стали характеризуватись як злочин, соціальний статус дітей значно підвищився, а самі діли стали об'єктом гуманного ставлення та спеціального правового захисту [4, с.103].

Ранні історичні суспільства, що існували на території України теж мали примітивні уявлення про право дитини. Сімейні правові традиції тогочасних племен, визначали повну належність батькам дитини його життя [5, с.253].

У часи Середньовіччя соціальне становище дитини набуває більш чітких рис у порівнянні з давнім часом і все більше формалізується. Становленню феномену прав дитини все більше сприяє релігійний фактор [1, с.43]. Християнство та іслам сприяють гуманізації соціального сприйняття права дитини, хоча гендерна нерівність, особливо в майновому сегменті правових відносин, існувала ще довго.

Варто відзначити, що розвиток філософії про права дитини невід'ємно прив'язаний до феномену прав та свобод людини, що почали формуватись ще в античні часи, однак сучасне розуміння цього явища розпочинається лише у пізньому середньовіччі. 3 розвитком писаного права норми, направлені на охорону та захист прав дітей, починають закріплюватись у писаних джерелах. Так, у тексті Салічної правди передбачався інститут опіки батька над дитиною. В судебнику Альфреда Великого, англійському кодексі IX століття, містилося положення про охорону ненародженої дитини, а також норми відповідальності за вбивство дитини [6].

Вітчизняній науці відомий перший випадок правового забезпечення гарантій прав і свобод дітей ще за часів існування Київської Русі (тобто з кінця IX до середини XIII ст.). Зокрема, у тексті Руської правди містились норми, що захищали права дітей при спадкуванні [7, с.37].

Однак у правових нормах, закріплених у писемних правових пам'ятках Київської Pусі, дитина визначалась виключно як суб'єкт майнових і немайнових прав. Водночас вказані норми мали становий характер, що повністю відповідало тогочасним стандартам права в цілому. Давньоруська традиція правового забезпечення захисту прав і свобод дитини під час відносин із дорослими певною мірою зберігалася і в 
Статутах Великого князівства Аитовського $[8$, c.73].

«Пакти й Конституції законів та вольностей Війська Запорозького», укладені 5 квітня 1710 р. у Бендерах, відомі як Конституція Пилипа Орлика, містили згадки про можливість закріплення гарантій прав дитини. Діти визнавались особливим суб'єктом права на освіту, а при православних церквах мало здійснюватись навчання дітей. Кодифікований акт правових норм різного походження від 1743 року, що діяли на Аівобережній Україні після їі приєднання до Росії «Права, за якими судиться малоросійський народ», містив норми, що закріплювали права дитини під час здійснення правосуддя, а саме неповноліття людини визнавалося як пом'якшуюча обставина при вчиненні злочину. «Зібрання малоросійських прав» унормував кодифікований акт 1807 року, який врегулював більшість цивільних відносин, уперше визначив поняття «неповнолітня особа» хлопці віком до 18 років і дівчата віком до 13 років, та інститути відносин, під якими ми сьогодні розуміємо правоздатність та дієздатність [9, с.52].

У Новому світі, перш за все у Сполучених Штатах Америки, до таких актів слід назвати Декларацію незалежності 1776 року, Конституцію СШІА 1787 року, Білль про права 1789 року.

У Франції в результаті досягнень Великої французької революції права людини грунтувались таким прогресивним на той час актом як Декларація прав людини і громадянина 1789 року. Хоча власне концепція прав людини та основних свобод як правових категорій виникла у Европі у XIII столітті. Філософія прав людини та основних свобод сформульована в творах видатних мислителів Гуго Гроція, Джона Локка, Едмонда Бурка, Томаса Пейна та інших [10, с.83].

Під час свого розвитку людство не відразу прийшло до розуміння того, що дитина 6 повноцінним членом суспільства, яка потребує спеціальної охорони і піклування, включаючи належний правовий захист. Дитина не розглядалася як представник окремої соціальної категорії досить довгий час. У правовому сенсі дитини не існувало зовсім, а в окремих державах, де в законодавчих актах йшлося про дитину, вона сприймалася як власність свого батька, і ставлення до неї було таким же, як до іншої власності.

У XVIII столітті, в епоху Просвітництва, діти стали розглядатися як окрема соціальна група.

Перетворення, викликані європейськими революціями XIX сторіччя, створили передумови для суспільного розуміння i розгляду прав дітей, їх захисту від рабства, економічної експлуатації, свавілля батьків. Так, у Великобританії в 1833 році була заборонена робота на фабриках дітям, які не досягли 9 років, а в 1842 році були введені обмеження щодо роботи дітей в шахтах. У 1896 році в Німеччині законом передбачається покарання батькам, які знущаються над своїми дітьми або мало про них піклуються. У 1899 році в СІІА створюються перші ювенальні суди, оскільки до цього діти розглядалися судом нарівні 3 дорослими. Шведська письменниця і педагог-реформатор Еллен Кей оголошує в 1900 р XX століття століттям дитини [11]. Дитина перестала сприйматися як власність батьків і стала частиною держави, а їі завданням було готуватися до справжнього дорослого життя.

Перехід людства до індустріального суспільства глибоко змінив як побут так i світогляд людей. Виникли матеріалістичні ідеології, пов'язані із секулярними тлумаченням історії та утопіями, досягнення яких повинно було здійснюватись за допомогою організованих бюрократичних структур. Що безумовно вплинуло на розвиток ювенального права. У цей період, заявили про себе принципово нові тенденції в осмисленні суспільної ролі дитини, перегляду методик і проблем виховання дитини у ранньому віці $[1,47]$.

Значний поштовх у напрямку розвитку ідей охорони та захисту прав дитини здійснили своїм впливом на цивільне населення наслідки Першої світової війни, формуючи зростаючий інтерес до проблеми охорони та захисту дітей в більшості країн Европи та Північної Америки. 


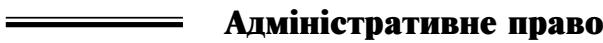

У 1919 році Аігою Націй був створений Комітет дитячого благополуччя. Він займався розробкою заходів, які необхідно було прийняти щодо безпритульних дітей, рабства, дитячої праці, торгівлі дітьми та проституції серед неповнолітніх.

При цьому, одну з головних ролей в розробці соціальних стандартів захисту дітей в той період відіграють неурядові організації, особливо Міжнародний союз порятунку дітей (Save the Children International Union), заснований безпосередньо після закінчення першої світової війни британської вчителькою і правозахисницею Еглантайн Джебб (Eglantyne Jebb).

Початком міжнародно-правової співпраці у галузі прав дитини вважають створення 1923 р. Міжнародної спілки захисту дітей [12, с.34]

У 1924 році за пропозицією Міжнародного союзу порятунку дітей в Женеві Аігою Націй була прийнята Декларація прав дитини. Декларація стала першим міжнародно-правовим документом у сфері охорони прав та інтересів дитини, вперше сформулювала цілі і принципи захисту його прав. Сприйняття дитини як категорії макросоціальної знайшло своє відображення у Декларації 1924 року. Однак без диференціації права в залежності від віку людини: «Всі люди народжуються вільними і рівними у своїй гідності та правах» (ст.1) [13].

Женевська Декларація прав дитини сформулювала чотири принципи, які були покладені в основу міжнародно-правового захисту дітей:

перший принцип: дитині повинна надаватися можливість нормального розвитку (матеріального і духовного). Голодна дитина повинна бути нагодована, хворій дитині необхідно надати догляд, порочні діти повинні бути виправлені, сиротам і безпритульним дітям повинно бути надано прихисток і все необхідне для їхнього існування;

другий принцип: дитина повинна бути першою, хто отримає допомогу при небезпеці;

третій принцип: дитині повинна бути надана можливість заробляти кошти на іс- нування, але вона повинна бути відгороджена від усіх форм експлуатації;

четвертий принцип: дитина повинна виховуватися з усвідомленням того, що іiі кращі якості будуть використані на благо наступного покоління.

Женевська Декларація прав дитини втратила правову основу в 1946 р, після розпаду Аіги Націй. Але вже в 1948 р. Організація Об'єднаних Націй прийняла Загальну декларацію прав людини, в якій проголошується, що всі діти мають право на особливе піклування і допомогу.

Aле, на жаль, декларація не змогла згуртувати держави для міжнародного співробітництва в цій галузі, головним чином, через відсутність єдиних принципів взаємодії і механізмів реалізації норм. Держави зверталися до цієї декларації лише фрагментарно з окремих питань в галузі охорони прав дитини. Відтак міжнародний захист прав дитини як система правових норм ще довго не міг сформуватися $[14$, c.10].

Як складова частина захисту прав людини система міжнародного захисту прав дитини склалася лише після Другої світової війни в рамках Організації Об'єднаних націй, одним з основоположних принципів якої було проголошення поваги до прав $\mathrm{i}$ свобод людини без будь-якої дискримінації. Цей принцип був закріплений в преамбулі Статуту цієї організації [15].

10 грудня 1948 року Генеральною Асамблеєю ООН була прийнята Загальна декларація прав людини, в преамбулі до якої йдеться, що визнання людської гідності, рівних і невід'ємних прав є основою свободи, справедливості та загального миру [16]. В ході подальшого розвитку прав людини відбулося виділення у цій галузі окремих інститутів, одним з яких в сучасному міжнародному праві $\epsilon$ інститут міжнародно-правового захисту прав дитини.

Виділенню міжнародно-правового захисту прав дитини сприяло подальше проголошення Декларації прав дитини 1959 року, прийнятої Генеральною Асамблеєю ООН. Декларація стала спеціальним документом, вперше повністю присвяченим 
правам дітей, преамбула якої зазначала, що дитина внаслідок їі фізичної і розумової незрілості, потребує спеціальної охорони і піклування, включаючи належний правовий захист як до, так і після народження.

У Декларації йдеться про недопущення щодо дітей дискримінації за будь-якими ознаками; про право дитини на нормальний розвиток; про право на отримання освіти. Відповідно до Декларації дитина повинна бути захищена від жорстокості та експлуатації; їй має надаватися право на належне харчування, житло, розваги і медичне обслуговування. Один 3 принципів Декларації встановлює обов'язок суспільства здійснювати особливе піклування про дітей, неповноцінних у фізичному, психічному або соціальному відношенні. Останній принцип присвячений питанням виховання дитини [17]. Таким чином. Декларація прав дитини 1959 року сформулювала принципи, на яких має базуватися державна політика щодо забезпечення прав дитини.

7 грудня 1965 року на 1390-му пленарному засіданні ООН була прийнята Декларація про розповсюдження серед молоді ідеалів миру, взаємної поваги і взаєморозуміння між народами. Декларація грунтується на наступних документах: Загальної декларації прав людини, резолюції 1572 (XV) Генеральної Асамблеї від 18 грудня 1960 р Декларації про надання незалежності колоніальним країнам і народам, Декларації ООН про ліквідацію всіх форм расової дискримінації, резолюції 110 (II) Генеральної Асамблеї від 3 листопада 1947 р засуджує всі види пропаганди, що має на меті або здатної створити або посилити загрозу миру, а також Декларації прав дитини [18].

Aле незважаючи на продуктивність і багатоаспектність нормотворчої діяльності в сфері охорони та захисту прав дитини, до кінця 70-х рр. стало очевидним, що існуючі норми 3 прав людини вже не є більше адекватними для того, щоб відповідати спеціальним потребам дітей. До того ж $з$ часу прийняття Декларації прав дитини були вироблені нові підходи, що стосуються концепції прав дітей та методів ïх захисту. Був потрібен єдиний міжнародний документ, який з'єднав би в собі весь попередній досвід нормотворчості і нові уявлення про захист прав дитини. Таким документом стала Конвенція про права дитини, прийнята 20 листопада 1989 року Генеральною Асамблеєю ООН резолюцією №44/25 [19]. Конвенція стала плодом десятирічної роботи багатьох фахівців. Перший проект Конвенції був представлений в Комісію з прав людини ООН в 1978 році. У розробці документа брали участь не лише представники держав і міжурядових організацій структури ООН, але й учені, а також неурядові організації, але тільки через десять років, 20 листопада 1989 року Генеральна асамблея ООН схвалила резолюцію № 44/25, прийнявши тим самим Конвенцію про права дитини. У день відкриття Конвенції для підписання, 26 січня 1990 року, їі підписала 61 країна, що стало свого роду рекордом серед нормативноправових актів підписаних в один день. Вважається, що Конвенція про права дитини близька до того, щоб стати першим у світі міжнародним договором з прав людини, який ратифікують усі країни світу.

Ухвалення Конвенції стало значною подією у сфері охорони та захисту прав дітей: дитина вперше стала розглядатися не лише як об'єкт, який потребує спеціального захисту, але і як суб'єкт права, якому надано повний перелік прав людини.

У порівнянні з Декларацією про права дитини 1959 року, яка містила 10 коротких, декларативного характеру положень, які іменувалися принципами, конвенція складається з статей, які враховують практично всі моменти, пов'язані 3 життям i становищем дитини в суспільстві. Конвенція про права дитини не тільки розвиває і конкретизує положення Декларації прав дитини, але і йде далі, стверджуючи, що держави, які до неї приєднуються, несуть юридичну відповідальність за свої дії щодо дітей [1].

Конвенція, що складається 354 статей, охоплює як громадянсько-політичні, так i соціально-економічні та культурні права дітей 3 моменту народження і до досягнення повноліття (18 років), якщо націо- 
нальним законодавством не передбачено більш ранній вік досягнення повноліття. 3 прийняттям Конвенції було введено ряд нових прав дитини: на виживання і розвиток (ст.6), на збереження індивідуальності (ст.8), на право вільно висловлювати свої погляди (ст. 12), на неучасть у військових діях (ст.38), на фізичне і психологічне відновлення і соціальну реінтеграцію жертв зловживань та експлуатації (ст.39). У Конвенції особливо обумовлена роль засобів масової інформації: держави-учасниці зобов' язані сприяти засобам масової інформації у поширенні інформації і матеріалів, корисних для дитини в соціальному і культурному відношенні, щоб дитина мала доступ до інформації з різних національних i міжнародних джерел. Держави учасники зобов'язуються «широко інформувати про принципи і положення Конвенції як дорослих, так і дітей». Ідеї Конвенції безпосередньо стосуються загальнолюдських проблем. Її називають «Великою хартією вольностей для дітей», «Світовою Конституцією прав дитини». Передбачається, що стандартами, встановленими Конвенцією, стануть користуватися всі ті. хто зацікавлений у вирішенні проблем, пов'язаних зі здоров'ям, розвитком і захистом дітей.

Конвенція, як усіма визнаний і авторитетного документа, буде виступати на захист дітей в усьому світі [20, с.76].

Важливе значення серед міжнародноправових актів, направлених на охорону та захист прав дітей, має документ, затверджений Генеральною Асамблеєю ООН S-27/2 «Світ, сприятливий для дітей». У ньому глави держав і урядів зобов’язалися, діючи на національному рівні, завершити те, що залишилося незавершеним в порядку денному Всесвітньої зустрічі на вищому рівні. Крім того, вони взяли на себе зобов'язання також вирішити інші нові питання, що має життєво важливе значення в інтересах дітей. Зокрема, одним із принципів наголошується на необхідності прислухатися до дітей і забезпечити їх участь. Оскільки діти і підлітки є творчими громадянами, здатними надати допомогу в побудові кращого майбутнього для всіх, необхідно поважати їх право висловлювати свою думку і брати участь у вирішенні всіх питань, які стосуються їх, з урахуванням віку та зрілості. Разом 3 тим, наголошується на необхідності розробки та здійснення програм, спрямованих на сприяння конструктивної участі молоді в процесах прийняття рішень на місцевому та національному рівнях [21].

На думку О.М. Дручек, 3 прийняттям «Стратегії Ради Европи 3 прав дитини на період 2016-2021 рр.» [22] можливо вести мову про початок п'ятого етапу розвитку міжнародної системи захисту прав і свобод дитини. Стратегія містить норму про те, що діти в державах-членах РE мають право користуватися всіма правами людини, гарантованими Европейською конвенцією захисту прав людини і основних свобод, Конвенцією про права дитини та іншими міжнародно-правовими актами 3 прав людини. Згідно Стратегії, завданням для PE та країн-членів $є$ - зробити зазначені права реальністю для всіх дітей. Стратегія закріплюе пріоритетні напрями для гарантування прав дитини на найближчі п'ять років, а саме: 1) рівні можливості для всіх дітей; 2) участь всіх дітей; 3) життя, вільне від насильства для всіх дітей; 4) правосуддя, доброзичливе до всіх дітей; 5) права дитини в цифровому середовищі. Значення Стратегії для України полягає у тому, що нею визначається зміст державної ювенальної політики та скеровуються зусилля щодо їі реалізації [23, с.36].

\section{Висновок}

Порівняльно-історичні дані про розвиток міжнародного права щодо охорони та захисту прав дитини вказують на те, що нинішній його стан $є$ результатом тривалого і досить суперечливого становлення. Підвищений інтерес суспільства до вирішення проблеми охорони та захисту прав дітей свідчить про розвиток цінностей дитинства, турботи про підростаюче покоління на міжнародному рівні.

\section{Мітература}

1. Навроцький О.О. Забезпечення прав дитини в Україні : теоретичні і практичні засади адміністративно-правового регулювання: дис. ... док. юрид. наук: 12.00.07 / 
О.О. Навроцький Харківський нац. ун-т ім. В.Н. Каразіна. Харків, 2018. 473 с.

2. Сергеенко М.Е. Жизнь древнего Рима / М.Е. Сергеенко. СПб. : Аетний Сад; Нева, 2000. 368 с.

3. Воспитание в Древнем Китае. URL : https://studfile.net/preview/3842340/page:4/

4. История педагогики и образования : учебник для СПО / под общ. ред. А.И. Пискунова. - 4-е изд., пер. и доп. - М.: Издательство Юрайт, 2018. - 452 с.

5. Саблук С.А. Історичні передумови формування правового статусу дитини в Україні / С.А. Саблук. Університетські наукові записки. - 2006. - №3-4 (19-20). - С.253260 .

6. Андрей Тесля. История государства и права средневековой Англии VI - XII вв. URL : https://www.rummuseum.ru/lib_t/ angl00.php

7. Хрестоматія 3 історії держави і права України: У 2-х т.: Навч. посіб. для студ. юрид. спец. вищ. закл. освіти / За ред. В.Д. Гончаренка. - Вид. 2-ге перероб. і доп.: T. 1: 3 найдавніших часів до початку ХX ст. / Уклад. В.Д. Гончаренко, А.Й. Рогожин, О.Д. Святоцький. - К., 2000. - 726 с.

8. Толкачова Г.В. Еволюція правового забезпечення гарантій захисту прав і свобод дитини / Г.В. Толкачова // Часопис Київського університету права. - 2014. - №1. - C.72-76.

9. Стариченко А.О. Дотримання прав дитини, як чинник сталого розвитку демократичного суспільства / А.О. Стариченко // Траєкторії сталого розвитку українського суспільства: особистість і кульутра : зб. наукових доп. V міжнар. наук.-практ. конф., м. Маріуполь, 15 листоп. 2019 р. : в 2 ч. / Маріуп. держ. ун-т ; гол. ред. Ю.С. Сабадаш ; упоряд. С.В. Янковський. - Маріуполь : МДУ, 2019. - Ч.1. - 191 с. - С.50-55.

10. Никонов К. Современные теоретические аспекты института международноправовой защиты и правовой защиты и поощрения прав ребенка / К. Никонов // Московский журнал международного права. - 2009. - №1. - С.83-102.

11. Калинкина М.Ю. Международные документы в интересах детей и молодежи: особенности правовой защиты (ретроспективный анализ с XIX века по настоящее время) / М.Ю. Калинкина // Вопросы ювенальной юстиции. - 2008. №3(17). URL : http://juvenjust.org/index. php?showtopic $=917$

12. Буткевич В.Г. Буткевич В.Г., Войтович С.А., Григоров О.М., Заблоцька Л.Г. та ін. Міжнародне право: Основні галузі: підручник для студ. вищих навч. закл. за спец. «Міжнародне право», «Міжнародні відносини» / В.Г. Буткевич (ред.). Київ: Аибідь, 2004. - 814 c.

13. United Nations International Children's Emergency Fund (UNICEF) History. URL : http://www.fundinguniverse. com/company-histories/united-nationsinternational-children-s-emergency-fundunicef-history/

14. Агушева Г.Г. Защита прав ребенка: Международноправовой аспект / Г.Г. Агушева, Д. Баданин // Ювенальное право. Поморский университет. - 2005. - №2. - C.9-15.

15. Статут Організації Об'єднаних Націй URL : https://zakon.rada.gov.ua/laws/ show/995_010

16. Всеобщая декларация прав человека. Принята и провозглашена в резолюции 217 А (III) Генеральной Ассамблеи от 10 декабря 1948 года. URL : https://zakon. rada.gov.ua/laws/show/995_015

17. Декларація прав дитини. Прийнята резолюцією 1386 (XIV) Генеральної Асамблеї ООН від 20 листопада 1959 року. URL : https://zakon.rada.gov.ua/laws/show/995 384

18. Декларація про розповсюдження серед молоді ідеалів миру, взаємної поваги та взаєморозуміння між народами : Резолюція 2037 (XX) Генеральної Асамблеї OOH. URL : https://zakon.rada.gov.ua/laws/ show/995_289

19. Конвенція про права дитини (20 листопада 1989 року). URL : https://zakon. rada.gov.ua/laws/show/995_021

20. Долинская А.M. Права ребенка, охрана материнства и детства в международных документах / Долинская ․М. // Цивилист. - 2008. - №4. - С.75-77.

21. Декларація та План дій «Мир, придатний для життя дітей». URL : https:// zakon.rada.gov.ua/laws/show/995_b20 


\section{Адміністративне право}

\section{Y cmami soiucHeHо aналіз}

статті здійснено аналіз розватку та оновлення міжнародного права у сфері охорони та захисту прав дітей. Досліджувались джерела ювенального права від первинного уявлення про права дитини в античні часи, до формування на сучасному етапі стійкой системи міжнародних нормативно-правових актів. Наведено приклади розуміння прав дітей в доіндустріальний період. Причини активізаизї розвитку ідей охорони та захисту прав дитини та зростаючий інтерес до изіё проблеми на початку XX cm. пояснюються впливом на ицвільне населення наслідків Першої світовоі війни. Наведено хронологію прийняття міжнародних нормативно-правових актів у сфері охорони та захисту прав дітей.

Зроблено висновок, що розвиток міжнародного права щодо охорони та захисту прав дітей вказує на те, що нинішній його стан $е$ результатом тривалого $i$ досить суперечливого становлення. Підвищений інтерес суспільства до вирішення проблеми охорони та захисту прав дітей свідчить про розвиток изінностей дитинства, турботи про підростаюче покоління на міжнародному рівні.

Ключові слова: дитина, права, свободи, інтереси дитини, ювенальна політика, забезпечення прав $i$ свобод дитини, охорона прав дитини, Конвенція про права дитини.

22. Стратегія Ради Европи з прав дитини (2016-2021) URL: http://la-strada.org.ua/ ucp_mod_news_list_show_607.html.

23. Дручек О.М. Адміністративно-правовий статус Національної поліції України як суб'єкта забезпечення прав і свобод дитини [Текст] : автореф. дис. ... канд. юрид. наук : 12.00.07 / О.М. Дручек; Одес. держ. ун-т внутр. справ. - Одеса, 2018. - 254 с.

\section{SUMMARY}

The article deals with the development of international law in the field of children's rights protection. The conception of the rights of the child has been researched in the sources of law since ancient times to the present stage with a stable system of international legislation. Examples of the pre-industrial understanding of the rights of children have been provided. Intensification of the children rights protection and the growing interest to this problem in the early twentieth century has been explained by the impact of the World War I on the civilian population. The chronology of the adoption of international legislation on protection of children's rights has been given. The principles of the Geneva Declaration of the Rights of the Child, 1924 have been analyzed. The norms on children rights in the Universal Declaration of Human Rights, 1948 have been outlined. The basic principles of the Declaration of the Rights of the Child, 1959 have been elucidated. Examples of other international legislation in the field of protection of children's rights and their basic principles have been outlined. The Convention on the Rights of the Child, 1989 has been analyzed, its fundamental norms have been compared with other juvenile acts of international law.

It has been concluded that the development of international juvenile law and its current status is the result of a long and rather controversial formation. Increased public interest in protection of children's rights shows the development of childhood values and care of the younger generation at the international level.

Keywords: child, rights, freedoms, interests of the child, juvenile policy, protection of the rights and freedoms of the child, Convention on the Rights of the Child. 